\title{
PENGARUH RETURN ON ASSET DAN RETURN ON EQUITY TERHADAP DEBT TO EQUITY RATIO PADA PT. KALBE FARMA, TBK
}

\author{
Rizka Wahyuni Amelia ${ }^{1}$, Denok Sunarsi \\ ${ }^{1}$ Universitas Pamulang \\ email:dosen02465@unpam.ac.id \\ email:denoksunarsi@unpam.ac.id
}

\begin{abstract}
This study aims to determine the effect of Return on Assets and Return on Equity on Debt to Equity Ratio at PT. Kalbe Farma, Tbk. The method used was explanatory research with a sample of 85 respondents. The analysis technique uses statistical analysis with regression testing, correlation, determination and hypothesis testing. The results of this study Return on Assets have no significant effect on Debt to Equity Ratio of 1.4\%, the hypothesis test obtained significance of 0.749> 0.05. Return on Equity has a significant effect on Debt to Equity Ratio of $42.0 \%$, the hypothesis test obtained significance of $0.045<0.05$. Return on Assets and Return on Equity simultaneously have a significant effect on Debt to Equity Ratio of $94.5 \%$, hypothesis testing obtained significance of 0,000 <0.05.
\end{abstract}

Keywords: return on assets, return on equity, debt to equity ratio.

\begin{abstract}
ABSTRAK
Penelitian ini bertujuan untuk mengetahui pengaruh Return on Asset dan Return on Equity terhadap Debt to Equity Ratio pada PT. Kalbe Farma, Tbk. Metode yang digunakan adalah explanatory research dengan sampel sebanyak 85 responden. Teknik analisis menggunakan analisis statistik dengan pengujian regresi, korelasi, determinasi dan uji hipotesis. Hasil penelitian ini Return on Asset tidak berpengaruh signifikan terhadap Debt to Equity Ratio sebesar 1,4\%, uji hipotesis diperoleh signifikansi $0,749>0,05$. Return on Equity berpengaruh signifikan terhadap Debt to Equity Ratio sebesar 42,0\%, uji hipotesis diperoleh signifikansi 0,045 < 0,05. Return on Asset dan Return on Equity secara simultan berpengaruh signifikan terhadap Debt to Equity Ratio sebesar 94,5\%, uji hipotesis diperoleh signifikansi $0,000<0,05$..
\end{abstract}

Kata Kunci: return on asset, Return on equity, debt to equity Ratio.

\section{A. PENDAHULUAN}

Industri farmasi adalah industri yang berbasis ilmu pengetahuan yang padat riset. Salah satu hal yang tidak bisa dihindarkan adalah timbulnya persaingan tajam antar perusahaan farmasi. Oleh karena itu, perusahaan farmasi di Indonesia dituntut untuk mampu bersaing dengan cara membuat inovasi, promosi dan sistem pemasaran yang baik, serta kualitas produk yang optimal.

Pendanaan menjadi salah satu faktor untuk menghadapi persaingan. Pendanaan diperlukan untuk membangun dan menjamin kelangsungan perusahaan. Sumber pendanaan dapat berasal dari sumber modal asing yaitu sumber dana yang didapatkan dari luar perusahaan (kreditur) yang tidak ikut memiliki perusahaan tersebut seperti bank, perusahaan leasing, pemegang obligasi, dan lain sebagainya. Sumber pendanaan dari modal asing biasanya berwujud hutang, baik hutang jangka pendek 
maupun hutang jangka panjang. Sumber pendanaan juga dapat berasal dari internal perusahaan yang melakukan aktivitas bisnis. Sumber pendanaan ini disebut juga sumber pendanaan modal sendiri. Sumber pendanaan modal sendiri biasanya berwujud laba ditahan dan modal saham.

Modal saham merupakan investasi yang didapatkan dari investor yang membeli saham di pasar modal. Investor memilih membeli investasi saham dengan pertimbangan tingkat pengembalian atas dana yang mereka investasikan dalam bentuk dividen ataupun selisih dari harga beli dengan harga jual yaitu capital gain.

Hakikatnya tujuan dari perusahaan adalah untuk memakmurkan pemiliknya. Pada perusahaan yang berbentuk PT terbuka pemiliknya adalah pemegang saham. Salah satu cara perusahaan dalam memakmurkan pemegang saham adalah melalui maksimalisasi harga saham sehingga diperoleh capital gain. Debt to Equity Ratios merupakan rasio yang menunjukkan hasil atas jumlah aktiva yang digunakan dalam perusahaan. (Kasmir, 2014:201).

Harga pasar saham ditentukan oleh mekanisme pasar yaitu kekuatan permintaan dan penawaran suatu saham tersebut di pasar modal. Meningkatnya minat investor untuk memiliki suatu saham dipengaruhi oleh kualitas atau nilai saham di pasar modal. Tinggi rendahnya nilai saham sebenarnya tercermin pada kinerja keuangan perusahaan. Jika suatu perusahaan memiliki kinerja keuangan yang baik maka investor akan menanamkan modalnya, karena dapat dipastikan akan memperoleh keuntungan dari penanaman modal tersebut. Menurut Kasmir (2013:196), return on equity (ROE) merupakan rasio untuk mengukur laba bersih sesudah pajak dengan modal sendiri.

Perusahaan yang mempunyai kinerja keuangan yang baik adalah perusahaan yang mampu meningkatkan keunggulan kompetitifnya sehingga dapat bertahan dan memenangkan persaingan dalam dunia usaha. Perusahaan dan para pelaku bisnis mulai menyadari bahwa inovasi, sistem informasi, pengelolaan organisasi dan sumber daya manusia yang dimilikinya lebih bisa meningkatkan daya saingnya dari pada kepemilikan aset berwujud. Menurut Kasmir (2012:151), Debt to Equity Ratio merupakan rasio yang digunakan untuk menilai utang dengan ekuitas. Rasio ini dicari dengan cara membandingkan antara seluruh utang, termasuk hutang lancar dengan seluruh ekuitas. Jika rasionya meningkat, ini artinya perusahaan dibiayai oleh kreditor (pemberi hutang) dan bukan dari sumber keuangannya sendiri yang mungkin merupakan trend yang cukup berbahaya. Pemberi pinjaman dan 
Investor biasanya memilih Debt to Equity

Ratio yang rendah karena kepentingan mereka lebih terlindungi jika terjadi penurunan bisnis pada perusahaan yang bersangkutan. Dengan demikian, perusahaan yang memiliki Debt to Equity Ratio atau Rasio Hutang terhadap Ekuitas yang tinggi mungkin tidak dapat menarik tambahan modal dengan pinjaman dari pihak lain.

Berdasarkan latar belakang diatas, maka penulis akan mengambil judul dalam penelitian ini yaitu "Pengaruh Debt to Equity Ratio dan Return On Equity terhadap Debt to Equity Ratio pada PT. Kalbe Farma, Tbk periode 2008-2017”

\section{B. TINJAUAN PUSTAKA}

\section{Return on Asset}

Perusahaan penting dalam mengoptimalkan tujuan yang akan dicapai guna mencapai tingkat keuntungan yang diharapkan. Return on asset merupakan rasio untuk mengetahui laba perusahaan yang dihitung dari masa tertentu. Kasmir (2013:194)

\section{Return on Equity}

Tinggi rendahnya nilai saham tercermin pada kinerja keuangan perusahaan. Jika suatu perusahaan memiliki kinerja keuangan yang baik maka investor akan menanamkan modalnya, karena dapat dipastikan akan memperoleh keuntungan dari penanaman modal tersebut. Menurut Kasmir (2013:196), return on equity (ROE) merupakan rasio untuk mengukur laba bersih sesudah pajak dengan modal sendiri

\section{Debt to Equity Ratio}

Salah satu cara perusahaan dalam memakmurkan pemegang saham adalah melalui maksimalisasi harga saham sehingga diperoleh capital gain. Debt to Equity Ratios merupakan rasio yang menunjukkan hasil atas jumlah aktiva yang digunakan dalam perusahaan. (Kasmir, 2014:201).

\section{METODE PENELITIAN}

\section{Populasi}

Populasi dalam penelitian ini laporan keuangan selama 5 tahun PT. Kalbe Farma, Tbk

\section{Sampel}

Teknik pengambilan sampling dalam penelitian ini adalah samplel jenuh, dimana semua anggota populasi dijasikan sebagai sampel. Dengan demikian sampel dalam penelitian ini laporan keuangan selama 5 tahun.

\section{Jenis Penelitian}

Jenis penelitian yang dipakai adalah asosiatif, dimana tujuannya adalah untuk mengetahui mencari keterhubungan antara variabel

\section{Metode Analisis Data}

Dalam menganalisis data digunakan 
uji instrumen, uji asumsi klasik, regresi, koefisien determinasi dan uji hipotesis.

\section{PEMBAHASAN}

\section{Analisis Deskriptif}

Pada pengujian ini digunakan untuk mengetahui skor minimum dan maksimum, mean score dan standar deviasi dari masing-masing variabel. Adapun hasilnya sebagai berikut:

Tabel 1. Hasil Analisis Descriptive Statistics

Descriptive Statistics

\begin{tabular}{|c|c|c|c|c|c|}
\hline & $\mathrm{N}$ & $\begin{array}{c}\text { Mini } \\
\text { mu } \\
\text { m }\end{array}$ & $\begin{array}{c}\text { Max } \\
\text { imu } \\
\text { m }\end{array}$ & $\begin{array}{l}\text { Me } \\
\text { an }\end{array}$ & $\begin{array}{c}\text { Std. } \\
\text { Deviati } \\
\text { on }\end{array}$ \\
\hline ROA (X1) & 10 & $\begin{array}{r}14 . \\
5\end{array}$ & $\begin{array}{r}19 . \\
1\end{array}$ & $\begin{array}{r}16 . \\
67 \\
2\end{array}$ & 1.7444 \\
\hline ROE (X2) & 10 & $\begin{array}{r}17 . \\
7\end{array}$ & $\begin{array}{r}24 . \\
4\end{array}$ & $\begin{array}{r}21 . \\
82 \\
6\end{array}$ & 2.4578 \\
\hline $\operatorname{DER}(\mathrm{Y})$ & 10 & $\begin{array}{r}19 . \\
6\end{array}$ & $\begin{array}{r}39 . \\
2\end{array}$ & $\begin{array}{r}28 . \\
10 \\
3\end{array}$ & 6.6416 \\
\hline $\begin{array}{l}\text { Valid N } \\
\text { (listwise) }\end{array}$ & 10 & & & & \\
\hline
\end{tabular}

minimum sebesar $14,5 \%$ dan nilai maximum 19,1\% dengan rata-rata sebesar $16,67 \%$ dengan standar deviasi $1,744 \%$.

Return on Equity diperoleh nilai minimum sebesar $17,7 \%$ dan nilai maximum 24,4\% dengan mean score sebesar 21,82\% dengan standar deviasi $2,457 \%$.

Debt to Equity Ratio diperoleh varians minimum sebesar $19,6 \%$ dan nilai maximum 39,2\% dengan rata-rata sebesar $28,10 \%$ dengan standar deviasi $6,641 \%$.

\section{Analisis Verifikatif.}

Pada analisis ini dimaksudkan untuk mengetahui pengaruh variabel independen terhadap variabel dependen. Adapun hasil pengujian sebagai berikut:

\section{a. Analisis Regresi Linier Berganda}

Uji regresi ini dimaksudkan untuk mengetahui perubahan variabel dependen jika variabel independen mengalami perubahan. Adapun hasil pengujiannya sebagai berikut: Tabel 2. Hasil Pengujian Regresi Liner Berganda

\begin{tabular}{|c|c|c|c|c|c|}
\hline \multicolumn{6}{|c|}{ Coefficients $^{a}$} \\
\hline Model & \multicolumn{2}{|c|}{$\begin{array}{c}\text { Unstandar } \\
\text { dized } \\
\text { Coefficient } \\
\mathrm{s}\end{array}$} & $\begin{array}{c}\text { Stand } \\
\text { ardize } \\
d \\
\text { Coeffi } \\
\text { cients } \\
\text { Beta }\end{array}$ & $\mathrm{t}$ & $\begin{array}{c}\text { Sig } \\
\text {. }\end{array}$ \\
\hline 1 (Constant) & $\begin{array}{r}13 . \\
542\end{array}$ & 6.027 & & $\begin{array}{r}2 . \\
24 \\
7\end{array}$ & $\begin{array}{r}.05 \\
9\end{array}$ \\
\hline $\mathrm{ROA}(\mathrm{X} 1)$ & $\begin{array}{r}- \\
3.6 \\
71\end{array}$ & .451 & -.964 & \begin{tabular}{|r}
- \\
8. \\
13 \\
7
\end{tabular} & $\begin{array}{r}.00 \\
0\end{array}$ \\
\hline ROE (X2) & $\begin{array}{r}3.4 \\
71\end{array}$ & .320 & 1.284 & $\begin{array}{r}10 \\
.8 \\
41\end{array}$ & $\begin{array}{r}.00 \\
0\end{array}$ \\
\hline a. Dependent & Vari & able: I & $\overline{\operatorname{ERR}(Y}$ & & \\
\hline $\begin{array}{l}\text { Berdasarl } \\
\text { pada tabel } \\
\text { persamaan re }\end{array}$ & $\begin{array}{l}\text { kan } \\
\text { di } \\
\text { egresi }\end{array}$ & $\begin{array}{l}\text { hasil } \\
\text { atas, }\end{array}$ & $\begin{array}{l}\text { pengu } \\
\text { diper } \\
13,54\end{array}$ & $\begin{array}{l}\text { jian } \\
\text { oleh }\end{array}$ & \\
\hline
\end{tabular}


3,671X1 + 3,471X2. Dari persamaan tersebut dijelaskan sebagai berikut:

1) Konstanta sebesar 13,542 diartikan jika Return on Asset dan Return on Equity tidak ada, maka telah terdapat nilai Debt to Equity Ratio sebesar 13,542 point.

2) Koefisien regresi Return on Asset sebesar - 3,671, angka ini positif artinya setiap ada peningkatan Return on Asset sebesar - 3,671 maka Debt to Equity Ratio juga akan mengalami peningkatan sebesar $-3,671$ point.

3) Koefisien regresi Return on Equity sebesar 3,471, angka ini positif artinya setiap ada peningkatan Return on Equity sebesar 3,471 maka Debt to Equity Ratio juga akan mengalami peningkatan sebesar 3,471 point.

\section{b. Analisis Koefisien Korelasi}

Analisis koefisien korelasi dimaksudkan untuk mengetahui tingkt kekuatan hubungan dari variabel independen terhadap variabel dependen baik secara parsial maupun simultan. Adapun hasil pengujian sebagai berikut:
Tabel 3. Hasil Pengujian Koefisien Korelasi Return on Asset Terhadap Debt to Equity Ratio.

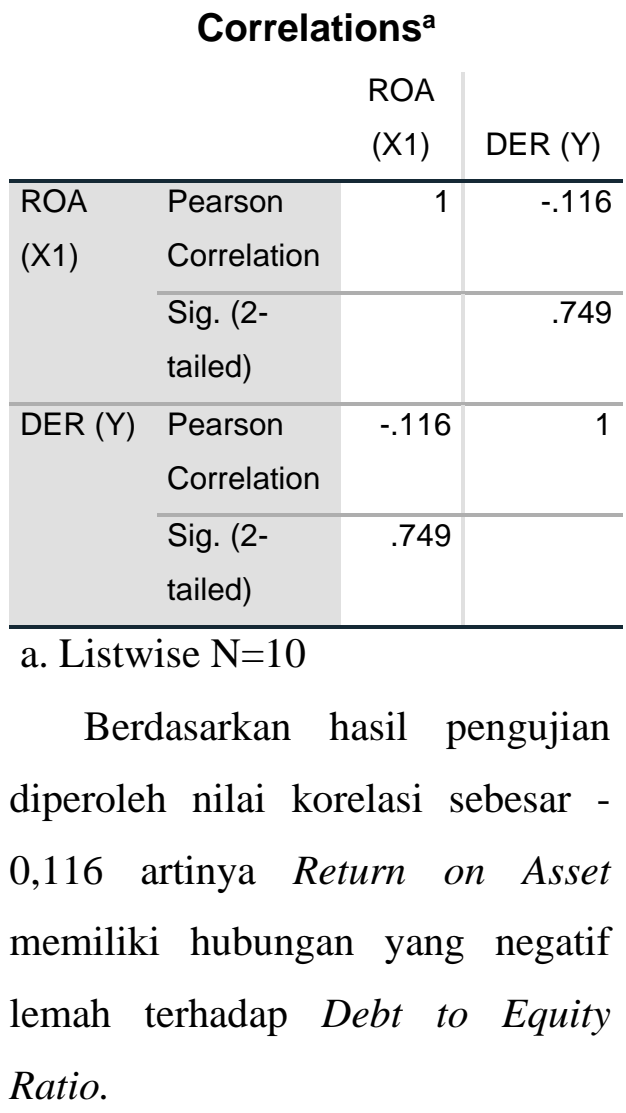

Tabel 4. Hasil Pengujian Koefisien Korelasi Return on Equity Terhadap Debt to Equity Ratio.

\section{Correlations $^{b}$}

ROE

(X2) DER (Y)

\begin{tabular}{|c|c|c|c|}
\hline \multirow[t]{2}{*}{$\begin{array}{l}\text { ROE } \\
(\mathrm{X} 2)\end{array}$} & $\begin{array}{l}\text { Pearson } \\
\text { Correlation }\end{array}$ & 1 & $.648^{*}$ \\
\hline & Sig. (2-tailed) & & .043 \\
\hline \multirow[t]{2}{*}{$\operatorname{DER}(\mathrm{Y})$} & $\begin{array}{l}\text { Pearson } \\
\text { Correlation }\end{array}$ & $.648^{*}$ & 1 \\
\hline & Sig. (2-tailed) & .043 & \\
\hline \multicolumn{4}{|c|}{ *. Correlation is significant at the 0.05 level } \\
\hline b. List & $\mathrm{N}=10$ & & \\
\hline
\end{tabular}


Berdasarkan hasil pengujian diperoleh nilai korelasi sebesar 0,648 artinya Return on Equity memiliki hubungan yang kuat terhadap Debt to Equity Ratio.

Tabel 5. Hasil Pengujian Koefisien Korelasi Return on Asset dan Return on Equity secara simultan Terhadap Debt to Equity Ratio.

\begin{tabular}{|c|c|c|c|c|}
\hline \multicolumn{5}{|c|}{ Model Summary } \\
\hline $\begin{array}{l}\text { Mod } \\
\text { el }\end{array}$ & $\mathrm{R}$ & $\begin{array}{c}\mathrm{R} \\
\text { Squar } \\
\mathrm{e}\end{array}$ & $\begin{array}{c}\text { Adjust } \\
\text { ed R } \\
\text { Squar } \\
\text { e }\end{array}$ & $\begin{array}{l}\text { Std. } \\
\text { Error of } \\
\text { the } \\
\text { Estimat } \\
e\end{array}$ \\
\hline 1 & $.972^{\mathrm{a}}$ & .945 & .929 & $\begin{array}{r}1.7733 \\
3\end{array}$ \\
\hline
\end{tabular}

a. Predictors: (Constant), ROE

(X2), ROA (X1)

Berdasarkan hasil pengujian diperoleh nilai korelasi sebesar 0,972 artinya Return on Asset dan Return on Equity secara simultan memiliki hubungan yang sangat kuat terhadap Debt to Equity Ratio.

\section{c. Analisis Koefisien Determinasi}

Analisis koefisien determinasi dimaksudkan untuk mengetahui besarnya persentase pengaruh dari variabel independen terhadap variabel dependen baik secara parsial maupun simultan. Adapun hasil pengujian sebagai berikut:

Tabel 6. Hasil Pengujian Koefisien Determinasi Return on Asset
Terhadap Debt to Equity Ratio.

\section{Model Summary}

\begin{tabular}{ll|r|r|c} 
& & & $\begin{array}{c}\text { Std. } \\
\text { Adjust } \\
\text { Mode }\end{array}$ & $\begin{array}{c}\text { Error of } \\
\text { ed R }\end{array}$ \\
the \\
I & $\mathrm{R}$ & $\mathrm{R}$ & $\begin{array}{c}\text { Squar } \\
\text { Estimat }\end{array}$ \\
\hline 1 & $.116^{\mathrm{a}}$ & .014 & -.110 & 6.99675 \\
\hline
\end{tabular}

a. Predictors: (Constant), ROA (X1)

Berdasarkan hasil pengujian diperoleh nilai determinasi sebesar 0,014 artinya Return on Asset memiliki kontribusi pengaruh sebesar $1,4 \%$ terhadap Debt to Equity Ratio.

Tabel 7. Hasil Pengujian Koefisien Determinasi Return on Equity Terhadap Debt to Equity Ratio.

\section{Model Summary}

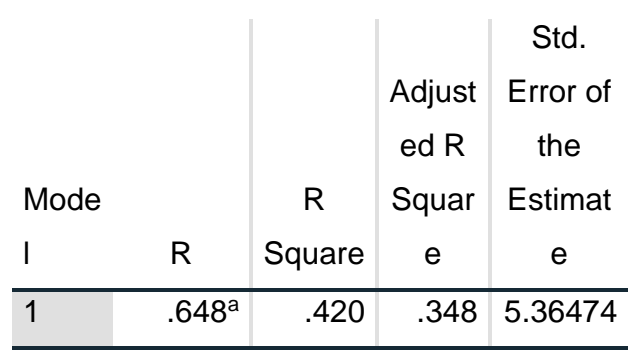

a. Predictors: (Constant), ROE (X2)

Berdasarkan hasil pengujian diperoleh nilai determinasi sebesar 0,420 artinya Return on Equity memiliki kontribusi pengaruh sebesar $42,0 \%$ terhadap Debt to Equity Ratio.

Tabel 8. Hasil Pengujian Koefisien Determinasi Return on Asset dan Return on Equity Terhadap Debt to Equity Ratio. 
Model Summary

\begin{tabular}{|c|c|c|c|c|}
\hline $\begin{array}{l}\text { Mo } \\
\text { del }\end{array}$ & $\mathrm{R}$ & $\begin{array}{c}\mathrm{R} \\
\text { Squar } \\
\mathrm{e}\end{array}$ & $\begin{array}{c}\text { Adjust } \\
\text { ed R } \\
\text { Squar } \\
e\end{array}$ & $\begin{array}{l}\text { Std. } \\
\text { Error of } \\
\text { the } \\
\text { Estimat } \\
e\end{array}$ \\
\hline 1 & $.972^{\mathrm{a}}$ & .945 & .929 & $\begin{array}{r}1.7733 \\
3\end{array}$ \\
\hline
\end{tabular}

a. Predictors: (Constant), ROE (X2), ROA (X1)

Berdasarkan hasil pengujian diperoleh nilai determinasi sebesar 0,945 artinya Return on Asset dan Return on Equity secara simultan memiliki kontribusi pengaruh sebesar $94,5 \%$ terhadap Debt to Equity Ratio, sedangkan sisanya sebesar $5,5 \%$ dipengaruhi faktor lain.

\section{d. Uji Hipotesis}

\section{Uji hipotesis Parsial (Uji t)}

Pengujian hipotesis dengan uji $\mathrm{t}$ digunakan untuk mengetahui hipotesis parsial mana yang diterima.

Hipotesis pertama: Terdapat pengaruh yang signifikan antara Return on Asset terhadap Debt to Equity Ratio.

Tabel 9. Hasil Uji Hipotesis Return on Asset Terhadap Debt to Equity Ratio.

\section{Coefficients $^{a}$}

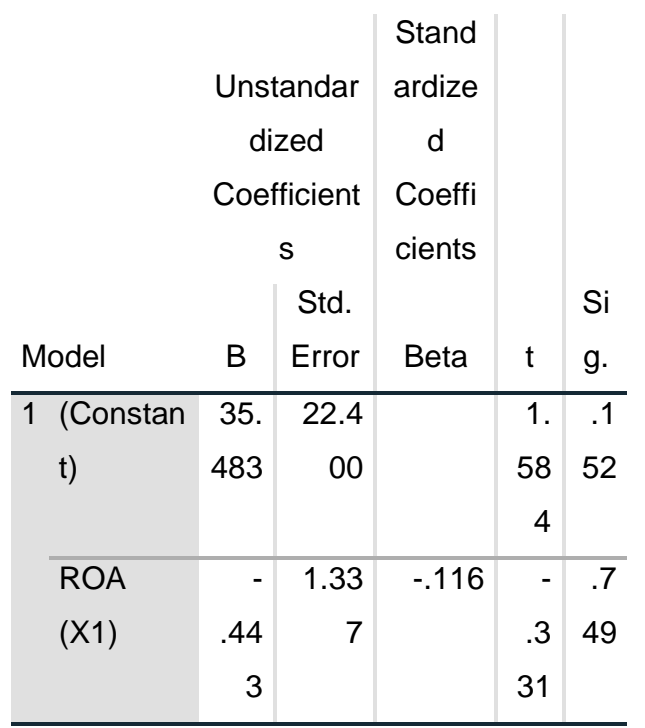

a. Dependent Variable: DER (Y)

Berdasarkan hasil pengujian pada tabel di atas, diperoleh nilai $t$ hitung < $\mathrm{t}$ tabel atau $(-0,331<$ 2,306), dengan demikian hipotesis pertama yang diajukan bahwa terdapat pengaruh yang signifikan atara Return on Asset terhadap Debt to Equity Ratio ditolak.

Hipotesis kedua: Terdapat pengaruh yang signifikan antara Return on Equity terhadap Debt to Equity Ratio.

Tabel 10. Hasil Uji Hipotesis Return on Equity Terhadap Debt to Equity Ratio.

\begin{tabular}{ll|l|l|l}
\multicolumn{4}{l}{ Coefficients $^{\mathrm{a}}$} & \\
& & $\begin{array}{c}\text { Stand } \\
\text { ardize }\end{array}$ & & \\
& Unstandardiz & $\mathrm{d}$ & & \\
ed & Coeffi & & $\mathrm{Si}$ \\
Model & Coefficients & cients & $\mathrm{t}$ & $\mathrm{g}$.
\end{tabular}




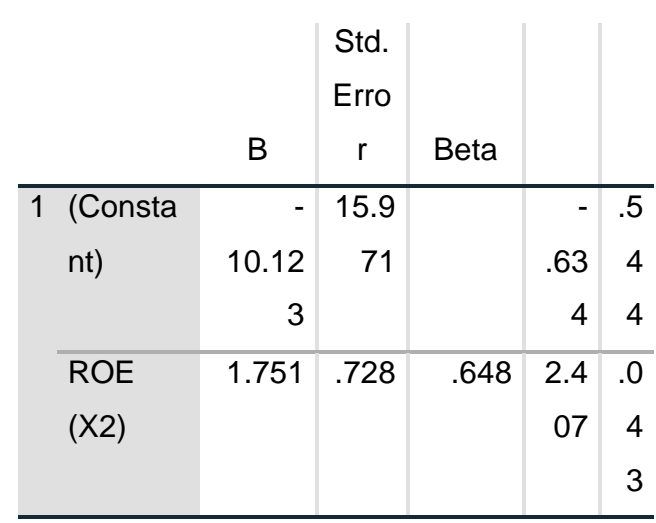

a. Dependent Variable: DER (Y)

Berdasarkan hasil pengujian pada tabel di atas, diperoleh nilai $\mathrm{t}$ hitung > t tabel atau $(2,407>2,306)$, dengan demikian hipotesis kedua yang diajukan bahwa terdapat pengaruh yang signifikan atara Return on Equity terhadap Debt to Equity Ratio diterima.

\section{Uji Hipotesis Simultan (Uji F)}

Pengujian hipotesis dengan uji $\mathrm{F}$ digunakan untuk mengetahui hipotesis simultan yang mana yang diterima.

Hipotesis ketiga Terdapat pengaruh yang signifikan antara Return on Asset dan Return on Equity terhadap Debt to Equity Ratio.

Tabel 11. Hasil Uji Hipotesis Return on Asset dan Return on Equity Terhadap Debt to Equity Ratio.

\begin{tabular}{|c|c|c|c|c|c|}
\hline \multicolumn{6}{|c|}{ ANOVA $^{a}$} \\
\hline & Sum of & & Mean & & \\
\hline & Square & $d$ & Squar & & $\mathrm{Si}$ \\
\hline Model & $\mathrm{s}$ & $f$ & e & $\mathrm{F}$ & g. \\
\hline
\end{tabular}

\begin{tabular}{ll|r|r|r|r|r}
\hline $\begin{array}{l}\text { Regressi } \\
\text { on }\end{array}$ & 374.990 & 2 & 187.4 & 59 & .0 \\
& & & 95 & .6 & 00 \\
22 & $\mathrm{~b}$ \\
\hline Residual & 22.013 & 7 & 3.145 & & \\
\hline Total & 397.003 & 9 & & & \\
\hline
\end{tabular}

a. Dependent Variable: DER (Y)

b. Predictors: (Constant), ROE (X2), ROA (X1)

Berdasarkan hasil pengujian pada tabel di atas, diperoleh nilai $\mathrm{F}$ hitung > F tabel atau (59,622> 4,070), dengan demikian hipotesis ketiga yang diajukan bahwa terdapat pengaruh yang signifikan atara Return on Asset dan Return on Equity terhadap Debt to Equity Ratio diterima.

\section{Pengaruh Return on Asset Terhadap} Debt to Equity Ratio

Return on Asset berpengaruh signifikan terhadap Debt to Equity Ratio dengan korelasi sebesar - 0,116 atau memiliki hubungan yang negatif lemah dengan kontribusi pengaruh sebesar 1,4\%. Pengujian hipotesis diperoleh nilai $t$ hitung $<\mathrm{t}$ tabel atau ($0,331<2,306)$. Dengan demikian hipotesis pertama yang diajukan bahwa terdapat berpengaruh signifikan antara Return on Asset terhadap Debt to Equity Ratio ditolak.

\section{Pengaruh Return on Equity Terhadap Debt to Equity Ratio}

Return on Equity berpengaruh 
signifikan terhadap Debt to Equity Ratio dengan korelasi sebesar 0,648 atau memiliki hubungan yang kuat dengan kontribusi pengaruh sebesar 42,0\%. Pengujian hipotesis diperoleh nilai $\mathrm{t}$ hitung > t tabel atau $(2,407>2,306)$. Dengan demikian hipotesis kedua yang diajukan bahwa terdapat berpengaruh signifikan antara Return on Equity terhadap Debt to Equity Ratio diterima.

4. Pengaruh Return on Asset dan Return on Equity Terhadap Debt to Equity Ratio

Return on Asset dan Return on Equity berpengaruh signifikan terhadap Debt to Equity Ratio dengan diperoleh persamaan regresi $\mathrm{Y}=13,542+-3,671 \mathrm{X} 1+$ 3,471X2, nilai korelasi sebesar 0,972 atau memiliki hubungan yang kuat dengan kontribusi pengaruh sebesar 94,5\% sedangkan sisanya sebesar $5,5 \%$ dipengaruhi faktor lain. Pengujian hipotesis diperoleh nilai $\mathrm{F}$ hitung $>\mathrm{F}$ tabel atau $(59,622>4,070)$. Dengan demikian hipotesis ketiga yang diajukan bahwa terdapat berpengaruh signifikan antara Return on Asset dan Return on Equity terhadap Debt to Equity Ratio diterima.

\section{F. KESIMPULAN}

1. Return on Asset tidak berpengaruh signifikan terhadap Debt to Equity Ratio dengan kontribusi pengaruh sebesar $1,4 \%$. Uji hipotesis diperoleh nilai t hitung $<\mathrm{t}$ tabel atau $(-0,331<$ $2,306)$.

2. Return on Equity berpengaruh signifikan terhadap Debt to Equity Ratio dengan kontribusi pengaruh sebesar 42,0\%. Uji hipotesis diperoleh nilai $\mathrm{t}$ hitung $>\mathrm{t}$ tabel atau $(2,407>2,306)$.

3. Return on Asset dan Return on Equity berpengaruh signifikan terhadap Debt to Equity Ratio dengan kontribusi pengaruh sebesar $94,5 \%$ sedangkan sisanya sebesar $5,5 \%$ dipengaruhi faktor lain. Uji hipotesis diperoleh nilai $\mathrm{F}$ hitung > F tabel atau $(59,622>$ $4,070)$.

\section{SARAN DAN UCAPAN TERIMAKASIH}

1. Perusahaan harus mengoptimalkan semua sumber daya perusahaan untuk mencapai profit yang lebih tinggi

2. Perusahaan harus mencari alternatif lain guna menarik investor agar modal bertambah.

3. Kinerja perusahaan dapat memperkuat nilai dbet to equity ratio agar nilai euitas meningkat

\section{DAFTAR PUSTAKA}

\section{Sumber dari Jurnal/Penelitian}

Kharis, Ismu Fadli (2011). Studi Mengenai Impulse Buying dalam Penjualan Online. Semarang: Skripsi Universitas Diponegoro. 
Rialmi, Z., \& Morsen, M. (2020). Pengaruh Komunikasi Terhadap Kinerja Karyawan PT Utama Metal Abadi. JENIUS, 3(2), 221-227.

Sunaryo. (2011). Pengaruh Current Ratio, Debt to Equity Ratio, dan Devidend Pay Out Ratio Terhadap Price Earning Ratio Pada Kelompok Perusahaan Manufaktur yang Terdaftar di Bursa Efek Indonesia Binus Business Review, Vol. 2 No. 2: 866-873.

Sunarsi. D, Aris Baharuddin. (2019). The Effect of Service Quality and Price Accuracy on Consumer Confidence and Implications for Sales Increase. PINISI Discretion Review, 3(2).

Sunarsi, D. (2019). The Analysis of The Work Environmental and Organizational Cultural Impact on The Performance and Implication of The Work Satisfaction. Jurnal Ilmiah Ilmu Administrasi Publik, 9(2), 113122.

\section{Sumber dari Buku}

Algifari. (2015). Analisis Regresi untuk Bisnis dan Ekonomi. Yogyakarta: BPFE.

Arikunto, Suharsimi (2014). Prosedur Penelitian Suatu Pendekatan Praktek. Jakarta: Rineka Cipta.

Imam Ghozali (2017). Aplikasi Analisis Multivariate dengan Program SPSS. Edisi Kelima. Semarang: Badan Penerbit Undip.

Istijanto (2014) Riset Sumber Daya Manusia. Jakarta: PT. Gramedia Pustaka

Kasmir (2008). Analisi Laporan keuangan. Jakarta: RajaGrafindo Persada.

Ni Putu Yuria Mendra (2016). Pengaruh Rasio Keuangan terhadap Price Earing Ratio pada Perusahaan Manufaktur yang terdaftar di Bursa Efek Indonesia Tahun 2012-2014.
Universitas Mahasaraswati Denpasar.

Rao, Purba. (2012). Measuring Consumer Perceptions Through Factor Analysis. The Asian.

Santoso, Singgih. (2015). Menguasai Statistik Multivariat. Jakarta: PT Elex Media Komputindo.

Sartono. (2013). manajemen keuangan teori konsep \& aplikasi. Yogyakarta: EKONISIA.

Sudjana. (2014). Metode Statistika”, Bandung: Tarsido.

Sugiyono. (2017). Metode Penelitian Administrasi: dilengkapi dengan Metode $R \& D$. Bandung: Alfabeta.

Suhartanto. (2014). Metode Riset Pemasaran. Bandung: Alfabeta

Sunarsi, D. (2018). Buku Ajar: Seminar Perencanaan Sumber Daya Manusia. Tangerang Selatan: Asmoro Mediatama

Sunarsi, D., \& MM, C. Pengaruh Kepemimpinan dan Budaya Organisasi Terhadap Kinerja Karyawan pada Bank DKI Cabang Pembantu Pondok Labu-Jakarta Selatan. 